\title{
The Effect of Ultraviolet Light Exposure on Proximate Composition, Amino Acid, Fatty Acid and Micronutrients of Cold Water Fish, "Barilius vagra”
}

\author{
VIVEK SHARMA $^{1 *}$, ABHISHEK SRIVASTAVA ${ }^{1}$ and VINOD KUMAR VASHISTHA ${ }^{1}$
}

'Department of Chemistry, G. L. A. University, Mathura, Uttar Pradesh-281406, India.

${ }^{*}$ Corresponding author E-mail: vivek.sharma @gla.ac.in

http://dx.doi.org/10.13005/ojc/350344

(Received: May 17, 2019; Accepted: June 17, 2019)

\begin{abstract}
Barilius vagrahas reached a position of importance in the hierarchy of class because of high abundance of protein and minerals. The effect of ultraviolet radiations on minerals, amino acid and fat content in fish, Barilius vagra was investigated at different time intervals $(1 \mathrm{~h}, 11 \mathrm{~h}$, and $21 \mathrm{~h})$. It was observed that UV radiations have no significant effect on composition of minerals, but total crude fat, crude protein and nitrogen content decreases significantly with increase in exposure time of UV radiation. The decrease in percentage of crude fat, crude protein, and nitrogen, after $21 \mathrm{~h}$ of irradiation was found to be $3.621,8.22$ and 3.568 respectively. Also the amino acid content in fish scale observed to decrease on exposure to UV light and the maximum decrease was observed in Valine after $21 \mathrm{~h}$ of ultraviolet exposure. The exposure to UV light shows a reduction in the weight of powdered scale. Therefore, assimilation of a small quantity of small fishes can considerably enhance the biological value of the diet and subsidize to momentous advances in nutritional security.
\end{abstract}

Keywords: Ultraviolet Irradiation, Crude protein, Amino acid, Crude fat, Barilius vagrahas.

\section{INTRODUCTION}

Fishes are considered as a significant cradle of animal protein and other minerals needed for growth of healthy body ${ }^{21}$. Fishes also comprise a significant amount of unsaturated fat, vitamins, and other essential nutrients. Amongst, all animal protein white-fleshed fish contain lower fat content. Oily fishes contain high amount of unsaturated fat (omega-3 fatty acids) and less amount of saturated fat (omega- 6 fatty acids) in comparison to red meat ${ }^{4}$.In India, there are about 2246 indigenous fish species have been reported, out of which 765 are fresh water including 450 as small indigenous fish (SIFs). In general, the fish having a length of 5 to $25 \mathrm{~cm}$ are considered as SIFs ${ }^{5,15}$. The SIFs encompass an important class of total finfish and shellfish population and subsidize considerably to the nutritious as well as means of support for the rural frame. They are appeared to be a rich source of nutrients and micronutrients. The SIFs deliver essential minerals to human nourishment as they are

This is an Open Access article licensed under a Creative Commons license: Attribution 4.0 International (CC- BY). Published by Oriental Scientific Publishing Company @ 2018 
eaten whole, with skin and bones ${ }^{11,14,17,18}$. The trace elements present in SIF include $\mathrm{Cu}, \mathrm{Zn}, \mathrm{Se}, \mathrm{Mg}, \mathrm{Fe}$, $\mathrm{Co}$, and $\mathrm{Cr}$. Further, along with these micro-minerals, they are rich in macro-minerals like $\mathrm{Ca}$ and $\mathrm{P}$. The SIFs are also rich in vitamins such as vitamin $A, D$, E, B1, B2 and B3. Small fishes play an important role in a providing nutrition for the population suffering from protein deficiency and malnutrition and also act as a source of income for poor people.

The Barilius vagra is from the family Cyprinidae and genus Barilius. It is a type of cold water fish and widely dispersed in the 'Brahmaputra and Ganges' river systems in northern India, Bangladesh and $\mathrm{Nepal}^{1,24}$. Due to its wide distribution, Barilius Vagra have been considered to be least concerned category in India, while it is endangered in Bangladesh due to habitat loss ${ }^{13}$. The length of fish ranges from $10 \mathrm{~cm}$ to $12.5 \mathrm{~cm}$ and is very attractive in color having a combination of varying shades ${ }^{8,25}$. Barilius vagra is essentially a surface-feeder and depends on smaller fishes, aquatic and terrestrial insects for its diet.

Human and animal cells, their protein and fat are sensitive to UV radiation (UVR) ${ }^{8,34}$. Due to the presence of the aromatic structure, the amino acids like phenylalanine, tryptophan and tyrosine can absorb UV light. On high exposure of UVR, phenylalanine and tyrosine were observed to affect maximum while proline and arginine were least affected $^{33}$.

Over a past few decade, efforts have been made on investigation of effects of UVR on aquatic systems. UVB (280-320 nm), the most damaging UVR reaching the Earth's surface, can enter to depths of water level down to 20 meters, based on water quality ${ }^{12,30}$. Amongst UVRs, UV-Bis considered to be most hazardous for aquatic creatures and also affect the productivity of marine eco-systems ${ }^{7,9,29}$. Such effect of UV-B on decrease in productivity of marine life (phytoplankton, heterotrophs, zooplankton and fishes) has been described in the literature $e^{2,6}$. Similar studies on fish eggs and larvae, though unusual, indicated that when exposed to UV-B (currently incident at the Earth's surface), aquatic life resulted into greater mortality that may lead to poorer adult populations ${ }^{33,34}$.

At the molecular level, UVR is able to damage proteins, lipids and DNA either through direct absorption of incident photons or through oxidative stress ${ }^{16}$.UVR induced oxidative stress may result from the generation of excessive levels of reactive oxygen species such as singlet oxygen (102), superoxide radical anion $\left(\mathrm{O}_{2}^{-2}\right)$, hydrogen peroxide $\left(\mathrm{H}_{2} \mathrm{O}_{2}\right)$ and hydroxyl radicals $\left(\mathrm{OH}^{-}\right)$through the excitation of endogenous chromophores (photo sensitizers). These species initiate macromolecular disorder either through direct oxidation reactions or through further activation of endogenous reactive intermediates.

In this study, the influence of UVR on crude fat, crude protein, and nitrogen, amino acid and mineral constituents present in scales of fish Barilius vagra was investigated. In this context, effects on proximate and fatty acid composition, vitamin and mineral contents, and nutritional values were investigated.

\section{MATERIALS AND METHODS}

Fishes (Barilius vagra) were collected from different aquatic bodies (ponds and Ganga River, Uttarakhand, India), in order to investigate the effect of temperature and water quality on fish composition. To avoid ambiguity, due to environment and habitat, the fish were collected from the exactly same place and during the same time duration (in the first week of May). The weight and length of the fish were recorded after collection. The fishes having a length around $12 \mathrm{~cm}$ were selected for analysis. Fish were properly washed with distilled water and scales were taken out from the fish body. After drying for about $48 \mathrm{~h}$ at $25^{\circ} \mathrm{C}$, the dried fish scales were finally homogenized with an electric grinder. The powdered samples were stored in the refrigerator before further use.

\section{Moisture and Ash}

Proximate analysis of moisture was carried out using the procedure reported in the literature ${ }^{27}$. 
However, a brief procedure is as follows: a constant weight of scale was obtained by keeping $1.0 \mathrm{~g}$ of powdered sample in an electric oven at $110^{\circ} \mathrm{C}$ for 24 hours. The ash content was determined by heating the powdered fish scale in a muffle furnace at $750^{\circ} \mathrm{C}$ until the constant weight of ash was obtained.

\section{Minerals}

Estimation of $\mathrm{Ca}$ and $\mathrm{F}$ was carried out using a method involving combination of precipitation and titration ${ }^{28} .100 \mathrm{mg}$ of ash was dissolved in hot $\mathrm{HCl}$ and the $\mathrm{Ca}^{2+}$ thus obtained was precipitated as calcium oxalate by using ammonium oxalate in acidic medium. The precipitates were then dissolved in dilute $\mathrm{H}_{2} \mathrm{SO}_{4}$; calcium was determined by titrating the liberated oxalic acid with $\mathrm{KMnO}_{3}$. The method developed by Snell and Snell was used to find the amount of fluorine present in fish scale $^{31}$. Magnesium was estimated by the colorimetric method after removing calcium in form of its sulphate precipitates. Sodium was determined gravimetrically as $\mathrm{NaZn}\left(\mathrm{UO}_{2}\right)_{3}\left(\mathrm{C}_{2} \mathrm{H}_{3} \mathrm{O}_{2}\right)_{9} \cdot 6 \mathrm{H}_{2} \mathrm{O}$ (hydrated triple salt). The aqueous solution of the salt was made alkaline using ammonium carbonate and then hydrogen peroxide was added to get yellow to orange to the red color solution. The color of the solution depends on the concentration of the uranyl ion. Phosphorus was determined as ammonium phosphomolybdate, which can be prepared by heating ammonium orthomolybdate with nitric acid and phosphoric acid. The method involves the decomposition of phosphomolybdate by an excess of standard $\mathrm{NaOH}$ and titrating the excess alkali with standard acid. The method reported by Cumming and Kay (1965) was used to determine $\mathrm{CO}_{2}$ using Schrotter's apparatus ${ }^{3}$.

\section{Protein, Amino acids, and Fat}

The kjeldhalmethod was used to find out the total nitrogen present in $100 \mathrm{~g}$ of dry scale powder and crude protein was calculated from total nitrogen by multiplying it by 6.25 . Quantification and identification of amino acids were done by high performance liquid chromatography after hydrolysis with $6 \mathrm{M} \mathrm{HCl}$. Crude fat was determined using a Soxhlet extractor by heating sample powder with petroleum ether for minimum 6 hours.

\section{RESULT AND DISCUSSION}

Minerals are considered as the spark plugs of the life and keystones to our health. Minerals are the catalysts that keep our body going and hold it charged. Calcium, magnesium, phosphorus, sodium, and fluoride are the few important minerals for maintaining the physiological processes and are the constituents of bones, teeth, blood, tissues, nerve cells and muscle. Barilius vagra has a significantly higher level of phosphorus and calcium in its scale. It also has a low content of magnesium, traces of sodium and fluorine (Table 1). After exposure of ultra violet for one $\mathrm{h}$ the minerals $(\mathrm{P}, \mathrm{Ca}, \mathrm{Mg}, \mathrm{F}$ and $\mathrm{Na}$ ) and carbon dioxide content remains unaltered while the extensive change in the moisture content was observed. The moisture content in the scales further decreased when UV light was exposed for $21 \mathrm{~h}$ but there is still no change in minerals $(\mathrm{P}, \mathrm{Ca}, \mathrm{Mg}, \mathrm{F}$ and $\mathrm{Na}$ ) and carbon dioxide content (Table 2).

Long chain $\mathrm{n}^{-3}$ polyunsaturated fatty acids (PUFA) must be obtained through the diet because they can't be synthesized by humans. Fish lipids are the major dietary source of polyunsaturated fatty acids (PUFA) such as eicosapantaenoic acid and docosahexaenoic acid for human. Docosahexaenoic acid is required for the proper development and functioning of the brain and reduces the age related brain problem ${ }^{19,26}$. Regular consumption of fish fat decreases the risk of heart disease by significantly lowering the triglycerides levels. Nitrogen, crude protein and crude fat of fish Barilius vagra before application of UV light is reported in Table 3. After 1,11 and $21 \mathrm{~h}$ exposure of ultra violet light, the decrease in fat content was 3.98, 5.40 and $8.22 \%$ respectively (Table 4).This is due to the oxidative decomposition of fat. PUFA $\left(n^{-3}\right)$ are highly prone to oxidative degradation. The oxidation of $n^{-3}$ PUFA is influenced by many factors, including exposure to $\mathrm{O}_{2}$ and light, temperature, and fatty acid composition. The initial oxidation of fish oils produces hydroperoxides, which decompose into various free radicals. These radical further react with un-oxidized PUFA to generate additional hydro-peroxides and also form secondary oxidation products such as volatile ketones and alcohols. This oxidation produces rancid smells and off flavors. 
Table 1: Proximate composition of powdered scales of fish Barilius Vagra before application of UV light (g $100 / \mathrm{g}^{-1}$ of dry matter)

\begin{tabular}{|c|c|c|c|c|c|c|c|c|c|}
\hline $\begin{array}{l}\text { Average } \\
\text { Length } \\
\text { (cm) }\end{array}$ & $\begin{array}{l}\text { of nine } \\
\text { Weight } \\
\text { (gm) }\end{array}$ & $\begin{array}{l}\text { ish } \\
\text { Girth } \\
\text { (cm) }\end{array}$ & $\begin{array}{l}\text { Found Ash } \\
\text { Mean } \pm \\
\left(t^{\star} S D / \sqrt{n}\right)\end{array}$ & $\begin{array}{c}\text { Moisture } \\
\text { Mean } \\
\left(t^{\star} S D / \sqrt{ } n\right)\end{array}$ & \multicolumn{2}{|c|}{$\begin{array}{c}\text { Minerals } \\
\text { Mean } \pm\left(t^{\star} S D / \sqrt{ } n\right)\end{array}$} & $\begin{array}{l}\text { Mineral } \\
\text { oxide or } \\
\text { fluoride }\end{array}$ & $\begin{array}{l}\text { Found conc. } \\
\text { Mean } \pm \\
\left(t^{\star} S D / \sqrt{n}\right)\end{array}$ & $\begin{array}{l}\text { Found Ash } \\
\text { Mean } \\
\left(t^{\star} S D / \sqrt{n}\right)\end{array}$ \\
\hline 8.16 & 84.66 & 3.69 & $27.5 \pm 0.956$ & $10.67 \pm 0.67$ & $\begin{array}{l}\mathrm{Ca} \\
\mathrm{Mg} \\
\mathrm{Na} \\
\mathrm{P} \\
\mathrm{F}\end{array}$ & $\begin{array}{c}10.45 \pm 0.56 \\
0.33 \pm 0.066 \\
0.0028 \pm 0.0012 \\
5.333 \pm 0.126 \\
0.0016 \pm 0.0003\end{array}$ & $\begin{array}{l}\mathrm{CaO} \\
\mathrm{MgO} \\
\mathrm{Na}_{2} \mathrm{O} \\
\mathrm{P}_{2} \mathrm{O}_{5} \\
\mathrm{CaF}_{2} \\
\mathrm{CO}_{2} \\
\text { Total }\end{array}$ & $\begin{array}{c}14.64 \pm 0.147 \\
0.55 \pm 0.0026 \\
0.003 \pm 0.00015 \\
12.213 \pm 0.62 \\
0.003 \pm 0.00013 \\
0.113 \pm 0.0047 \\
27.406\end{array}$ & $0.094 \pm 0.0032$ \\
\hline
\end{tabular}

Where 't' represents student 't' value (at 0.05 selected degree of probability), $n(=5)$ is the number of replicates.

Table 2: Effect of U.V. irradiation on mineral constituents and ash content of Fish Barilius vagra (g $100 / g^{-1}$ of dry matter)

\begin{tabular}{|c|c|c|c|c|c|c|c|}
\hline $\begin{array}{l}\text { Time duration } \\
\text { of irradiation }\end{array}$ & $\begin{array}{c}\text { Found Ash } \\
\text { Mean } \pm\left(t^{\star} S D / \sqrt{ } n\right)\end{array}$ & $\begin{array}{l}\text { Moisture } \\
\left(t^{\star} S D / \sqrt{ } n\right)\end{array}$ & Miner & $\begin{array}{l}\text { ean } \pm \text { Mean } \pm \\
/ \sqrt{ } n)\end{array}$ & $\begin{array}{c}\text { Mineral } \\
\text { oxide/fluoride }\end{array}$ & $\begin{array}{l}\text { Found conc. } \\
\text { Mean } \pm\left(t^{\star} S D / \sqrt{ } n\right)\end{array}$ & $\begin{array}{c}\text { Found Ash } \\
\text { Mean } \pm\left(t^{*} S D / \sqrt{ } n\right)\end{array}$ \\
\hline $1 \mathrm{~h}$ & 26.9 & 9.98 & $\begin{array}{l}\mathrm{Ca} \\
\mathrm{Mg} \\
\mathrm{Na} \\
\mathrm{P} \\
\mathrm{F}\end{array}$ & $\begin{array}{c}10.5 \pm 0.47 \\
0.33 \pm 0.017 \\
0.0028 \pm 0.00014 \\
5.333 \pm 0.07 \\
0.0016 \pm 0.0012\end{array}$ & $\begin{array}{l}\mathrm{CaO} \\
\mathrm{MgO} \\
\mathrm{Na}_{2} \mathrm{O} \\
\mathrm{P}_{2} \mathrm{O}_{5} \\
\mathrm{CaF}_{2} \\
\mathrm{CO}_{2} \\
\mathrm{Total}^{2}\end{array}$ & $\begin{array}{c}14.7 \pm 0.89 \\
0.55 \pm 0.068 \\
0.003 \pm 0.0006 \\
12.213 \pm 0.98 \\
0.0033 \pm 0.0004 \\
0.113 \pm 0.007 \\
27.466\end{array}$ & $0.034 \pm 0.008$ \\
\hline $11 \mathrm{~h}$ & 27.5 & 9.93 & $\begin{array}{l}\mathrm{Ca} \\
\mathrm{Mg} \\
\mathrm{Na} \\
\mathrm{P} \\
\mathrm{F}\end{array}$ & $\begin{array}{c}10.5 \pm 0.57 \\
0.33 \pm 0.07 \\
0.0028 \pm 0.0021 \\
5.333 \pm 0.58 \\
0.0016 \pm 0.0041\end{array}$ & $\begin{array}{l}\mathrm{CaO} \\
\mathrm{MgO} \\
\mathrm{Na}_{2} \mathrm{O} \\
\mathrm{P}_{2} \mathrm{O}_{5} \\
\mathrm{CaF}_{2} \\
\mathrm{CO}_{2} \\
\mathrm{Total}^{2}\end{array}$ & $\begin{array}{c}14.7 \pm 0.447 \\
0.55 \pm 0.036 \\
0.003 \pm 0.0047 \\
12.213 \\
0.0033 \pm 0.00014 \\
0.0113 \pm 0.0053 \\
27.466\end{array}$ & $0.034 \pm 0.0038$ \\
\hline $21 \mathrm{~h}$ & 27.5 & 8.69 & $\begin{array}{l}\mathrm{Ca} \\
\mathrm{Mg} \\
\mathrm{Na} \\
\mathrm{P} \\
\mathrm{F}\end{array}$ & $\begin{array}{c}10.5 \pm 0.68 \\
0.33 \pm 0.014 \\
0.0028 \pm 0.00058 \\
5.333 \pm 0.28 \\
0.0016 \pm 0.0008\end{array}$ & $\begin{array}{l}\mathrm{CaO} \\
\mathrm{MgO} \\
\mathrm{Na}_{2} \mathrm{O} \\
\mathrm{P}_{2} \mathrm{O}_{5} \\
\mathrm{CaF}_{2} \\
\mathrm{CO}_{2} \\
\text { Total }\end{array}$ & $\begin{array}{c}14.7 \pm 0.78 \\
0.55 \pm 0.041 \\
0.003 \pm 0.0047 \\
12.213 \pm 0.121 \\
0.0033 \pm 0.001 \\
0.0113 \pm 0.004 \\
27.466\end{array}$ & $0.034 \pm 0.0026$ \\
\hline
\end{tabular}

Where 't' represents student 't' value (at 0.05 selected degree of probability), $n(=5)$ is the number of replicates.

Table 3: Nitrogen, Crude Protein and Crude Fat Contents of Fish Barilius vagra before application U.V. light (g $100 / g^{-1}$ of dry matter)

\begin{tabular}{|c|c|c|c|c|c|c|c|}
\hline \multicolumn{2}{|c|}{ Average of nine fish } & \multicolumn{2}{|c|}{ Nitrogen Mean $\pm\left(t^{\star} S D / \sqrt{ } n\right)$} & \multicolumn{2}{|c|}{ Crude Fat Mean $\pm\left(t^{\star} S D / \sqrt{ } n\right)$} & \multicolumn{2}{|c|}{ Crude protein Mean $\pm\left(t^{*} S D / \sqrt{ } n\right)$} \\
\hline \multirow{2}{*}{$\begin{array}{l}\text { Length }(\mathrm{cm}) \\
7.966\end{array}$} & \multicolumn{7}{|c|}{ Girth $(\mathrm{cm}) \quad$ Weight $(\mathrm{gm})$} \\
\hline & 3.69 & 84.66 & $11.23 \pm 0.14$ & \multicolumn{2}{|c|}{$0.2833 \pm 0.01$} & \multicolumn{2}{|c|}{$70.1875 \pm 0.589$} \\
\hline \multicolumn{8}{|c|}{ Total of Crude Protein + Ash + Crude Fat $=97.96$} \\
\hline \multicolumn{8}{|c|}{$\begin{array}{c}\text { Table 4: Effect of U.V. irradiation on total nitrogen, protein and crude fat of fish Barilius vagra (g } 100 / g^{-1} \text { of } \\
\text { dry matter) }\end{array}$} \\
\hline $\begin{array}{l}\text { Time duration } \\
\text { of irradiation }\end{array}$ & $\begin{array}{l}\text { Total N Mean } \\
\pm\left(t^{\star} \mathrm{SD} / \sqrt{ } \mathrm{n}\right)\end{array}$ & $\begin{array}{l}\text { Decrease in } \\
\% \mathrm{~N} \text { Mean } \\
\pm\left(t^{\star} S D / \sqrt{ } n\right)\end{array}$ & $\begin{array}{c}\text { Crude } \\
\text { fat Mean } \\
\pm\left(t^{\star} S D / \sqrt{ } n\right)\end{array}$ & $\begin{array}{l}\text { Decrease in crude } \\
\text { fat }(\%) \text { Mean } \\
\pm\left(t^{\star} S D / \sqrt{ } n\right)\end{array}$ & $\begin{array}{l}\text { Crude } \\
\text { Mean } \pm\end{array}$ & protein & $\begin{array}{c}\text { Decrease in crude } \\
\text { protein Mean } \\
\pm\left(t^{\star} S D / \sqrt{ } n\right)\end{array}$ \\
\hline $1 \mathrm{~h}$ & $11.1609 \pm 0.14$ & $0.623 \pm 0.01$ & $0.272 \pm$ & $3.98 \pm 0.89$ & 69.7 & $5 \pm 2.6$ & $0.612 \pm 0.08$ \\
\hline $11 \mathrm{~h}$ & $10.9413 \pm 0.26$ & $2.573 \pm 0.06$ & $0.268 \pm$ & $5.4 \pm 0.87$ & 68.3 & $37 \pm 3.6$ & $2.57 \pm 0.58$ \\
\hline $21 \mathrm{~h}$ & $10.8233 \pm 0.25$ & $3.621 \pm 0.08$ & $0.26 \pm$ & $8.22 \pm 1.01$ & 67.6 & $4 \pm 2.8$ & $3.568 \pm 0.91$ \\
\hline
\end{tabular}

Where 't' represents student 't' value (at 0.05 selected degree of probability), $n(=5)$ is the number of replicates.

Total (Crude fat + Ash + Crude protein) $=97.52$ (After $01 \mathrm{~h}$ application of U.V. light)

Total (Crude fat + Ash + Crude protein $)=96.13$ (After $11 \mathrm{~h}$ application of U.V. light)

Total (Crude fat + Ash + Crude protein) $=95.40$ (After $21 \mathrm{~h}$ application of U.V.light) 
Table 5: Amino Acids content in powdered scales of fish Barilius vagra before application of U. V. light (g $100 / g^{-1}$ of dry matter)

\begin{tabular}{ccc}
\hline S. No & Amino acids & \% Value Mean $\pm\left(t^{\star} \mathrm{SD} / \sqrt{ } \mathrm{n}\right)$ \\
\hline 1 & Tryptophan & $3.2 \pm 0.59$ \\
2 & Cysteine & $8.31 \pm 1.21$ \\
3 & Phenyl Alanine & $2.99 \pm 0.87$ \\
4 & Lysine & $2.4 \pm 0.54$ \\
5 & Leucine & $2.46 \pm 0.68$ \\
6 & Histidine & $3.69 \pm 0.81$ \\
7 & Isoleucine & $3.64 \pm 0.67$ \\
8 & Arginine & $4.92 \pm 0.45$ \\
9 & Methionine & $2.79 \pm 0.36$ \\
10 & Hydroxy proline & $5.25 \pm 0.47$ \\
11 & Proline & $2.83 \pm 0.49$ \\
12 & Cysteine & $2.42 \pm 0.41$ \\
13 & Valine & $3.8 \pm 0.2$ \\
14 & Serine* & $24.3 \pm 2.81$ \\
15 & Tyrosine & $1.9 \pm 0.14$ \\
16 & Aspartic Acid & $4.87 \pm 0.16$ \\
17 & Alanine & $6.87 \pm 0.24$ \\
18 & Glycine & $4.31 \pm 0.65$ \\
19 & Threonine & $5.36 \pm 0.61$ \\
20 & Glutamic Acid & $3.69 \pm 0.47$ \\
& Total & $100 \pm 0.65$ \\
\hline & &
\end{tabular}

Proteins are important for all the living beings and are major constituents of body fluids and hormones. Fish proteins enhance the overall protein quality of human diet as it contains all essential amino acids in requisite amount. A fresh fish contains $18-20 \%$ of good quantity protein having all essential amino acids including methionine, cysteine and sulphur-containing lysine ${ }^{22}$. The major amino acid of human skin collagen is glycine, it will form a polypeptide chain with other essential amino acids such as proline, alanine, arginine, isoleucine, phenyl alanine and serine that will support the growth and healing of tissue. Specific amino acids like glycine, glutamic acid, and aspartic acid play a vital role in wound healing ${ }^{23}$. Besides having high nutritive value protein also provide several health benefits, such as anti-mutagenicity, reduction of blood cholesterol, anti-obesity potential and reduction of coronary heart disease ${ }^{10,20,32}$.

Ultraviolet light degrades the collagen peptide into smaller molecules which leads to wrinkles and may contribute to skin cancers. Photo aging and skin damaging is suppressed by collagen peptide. After exposure to UV light for one, eleven and twenty-one $\mathrm{h}$ the protein content decreases to $0.612,2.57$ and 3.568 percentage respectively (Table 5). The content of amino acids in powdered scale have also been evaluated before (Table 6) and after 1, 11 and $21 \mathrm{~h}$ irradiation of U.V. light (Table 6). After exposure of UV light for one hour, the percentage of tryptophan (2.188) decreases maximum while valine decreases minimum $(0.526$ $\%)$. After continuous eleven hours of exposure to ultraviolet light, the maximum decrease is observed for glycine $(6.729 \%)$ whereas valine and tyrosine show a minimum decrease (1.579\%). Glycine shows maximum decrement $(8.121 \%)$ and valine shows minimum decrement $(2.632 \%)$ on $21 \mathrm{~h}$ of continuous exposure of UV light to powdered fish scale (Figure 1). Table 5: Effect of U.V. irradiation on amino acids content of scales of fish Barilius vagra ( $\mathrm{g} 100 / \mathrm{g}^{-1}$ of dry matter)

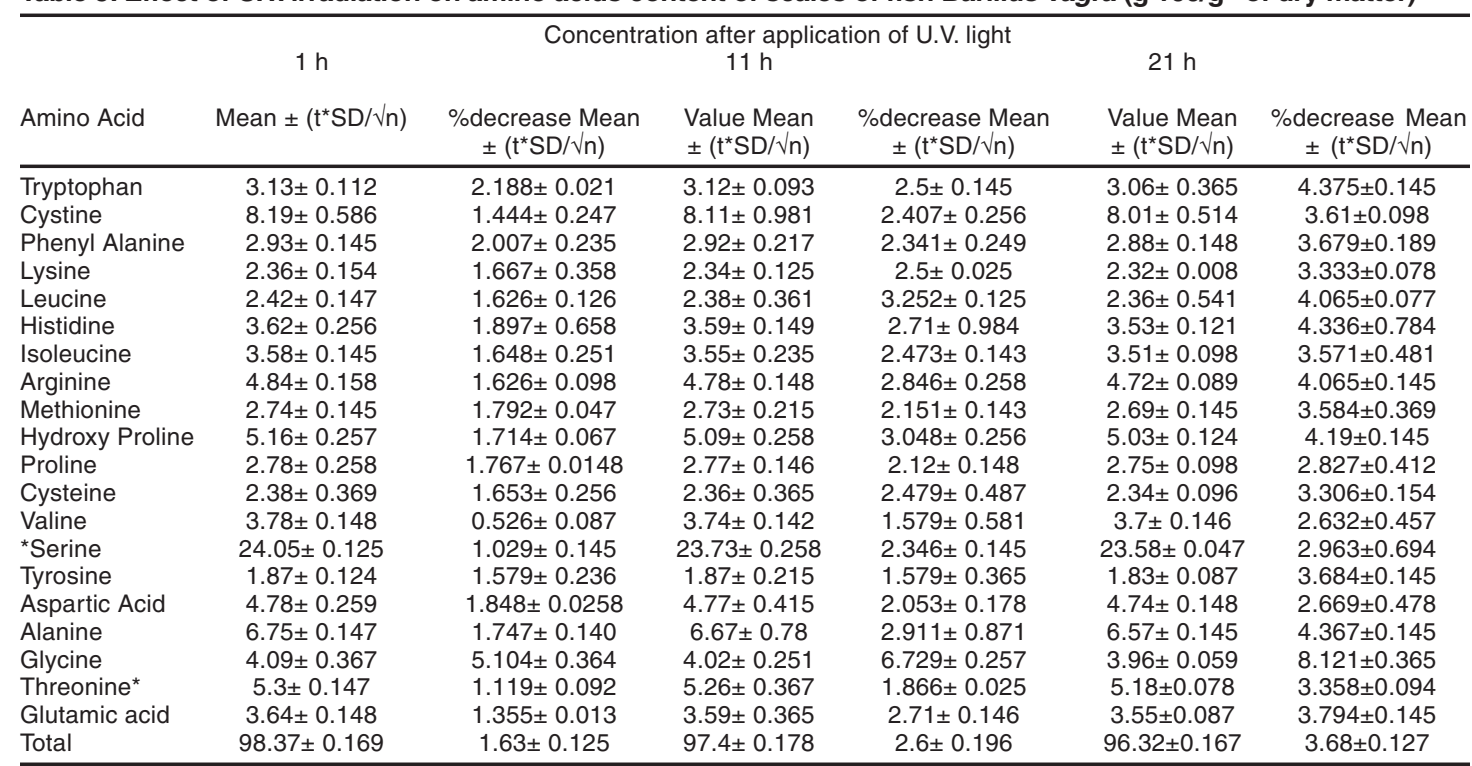

Where 't' represents student 't' value (at 0.05 selected degree of probability), $n(=5)$ is the number of replicates.

$\mathrm{N}$ - Terminal residue not calculate $-\mathrm{CONH}_{2}$ not calculate ${ }^{*}$ Corrected for the loss during hydrolysis 


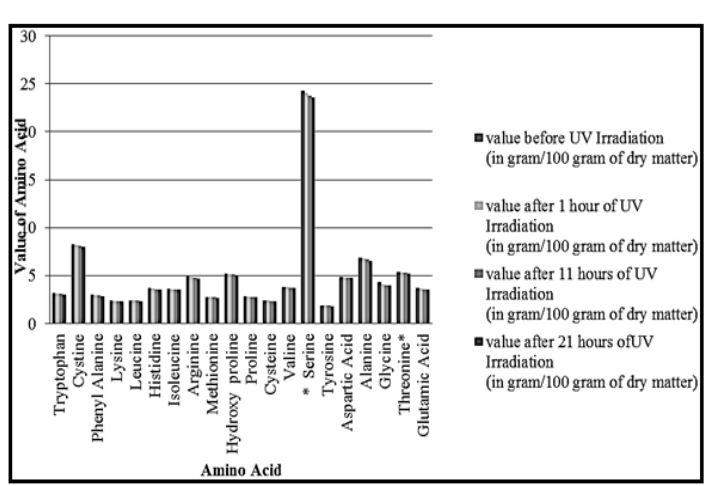

Fig. 1. Comparative study of amino acid content before and after U. V. irradiation of different time exposure

\section{CONCLUSION}

Small fishes play an important role in a providing nutrition for the population suffering from protein deficiency and malnutrition and also as a source of income for poor people. The present study concludes that there is no change in minerals and carbon dioxide content even after $21 \mathrm{~h}$ of exposure of UV-R, whereas moisture, total nitrogen, crude protein, and crude fat content decreases continuously. The decrease in individual amino acid content is also observed. Theamino acids content in powdered scale affected significantly on exposure to UVR. The maximum effect observed on the amino acids having aromatic moieties, this effect may be due to absorption of UVR through pi to $\mathrm{pi}^{*}$ transition. UVR hastened the decay of animal and vegetable fat resulting in odor and taste changes. Light absorbing compounds present in oil and fat sensitize them to ultraviolet and visible light. Prolonged exposure of UVR on acid soluble collagen results in the fission of peptide bond and cross-linking, while a very little damage is found to the amino acid residue.

\section{ACKNOWLEDGEMENT}

The author acknowledges the management of GLA University, Mathura for financial support and Principal of K.R. (PG) College, Mathura for allowing conducting experiment in their laboratory.

\section{Conflict of Interest}

No conflict of interest.

\section{REFERENCES}

1. Baishya, R. A.; Basumatary, S.; Kalita, H. K.; Talukdar, B.; Dutta, A.; Sarma, D. P. Indian Journal of Fisheries., 2016, 63(1), 1-7.

2. Booth, C. R.; Morrow, J. H.; Coohill, T. P.; Cullen, J. J.; Frederick, J. E.; Hader, D. P.; HolmHansen, Jeffrey, W. H.; Mtchell D. L.; Neale, P. J.; Sobolev, I.; van der Leun, J.; Worrest, R. C. Photochem Photobiol., 1997, 65, 252-269.

3. Cumming and Kay, Quantitaive chemical analysis revised by Robert Alaxander Chalmers, London., 1965, 111-112, 124-125, 332-334.

4. Dhaneesh, K. V.; Naushad, K.M.; Kumar, T.T. A. Plos One., 2012, 7(9), 45439.

5. Felts, R. A.; Fajts, F.; Akteruzzaman, M. Development of Inland Fisheries., 1996, 41, 201-211.

6. Hader, D. P.; (ed) The effects of ozone depletion on aquatic ecosystems. RG Landes Company, Austin, TX., 1997.

7. Hader, D. P.; Worrest, R. C.; Kumar, H. D.; Smith, R. C. Arnbio., 1995, 24, 174-180.

8. Hader, D. P.; Williamson, C. E.; Wangberg S. K.; Rautio, M.; Rose, K. C.; Gao, K.; Helbing, E. W.; Sinha, R. P.; Worrest, R. Photochemical and Photobiological Science., 2015, 14, 108.

9. Holm-Hansen, Lubin, D.; Helbling, E. W.; Ultraviolet radiation and its effects on organisms in aquatic environments. In: Young AR, Bjorn LO, Moan J, Nultsch W (eds) Environmental UV Photobiology. Plenum Press, New York, 1993, 379-425,

10. Hosomi, R.; Fukunaga, K.; Arai, H.; Kanda, S.; Nishiyama, T.; Yoshida, M. Journal of Food Sci., 2011, 76(4), 116-121.

11. Hossain, M. A.; Afsana, K.; Shah, A. K. M. Bangladesh J. Fish. Res., 1999, 3(1), 77-85,

12. Huovinen. P. S.; Penttila, H.; Soimasuo, M. R. Int. J. Circumpolar Health., 2000, 59, 15-21.

13. IUCN Bangladesh (2000) Red Book of Threatened Species of Bangladesh, IUCN-The World Conservation Union., 2000, XII-116.

14. Kongsbak, K.; Thilsted, S.H.;Wahed, M. A. British Journal of Nutrition., 2010, 99, 581-597.

15. Lakra, W. S.; Sarkar, U. K.; Gopalakrishnan, A.; Kathirvelpandian, A. Threatened Freshwater Fishes of India. NBFGR (ICAR), Lucknow., 2010.

16. Lchihashi, M.; Ueda, M.; Budiyanto, A.; Bito, T.; Oka, M.; Fukunaga, M.; Tsurs, K.; Horikawa, T. Toxicology., 2003, 189, 21-39. 
17. Mahanty, A.; Ganguly, S.; Verma, A.; Sahoo, S.; Mitra, P.; Paria, P.; Sharma, A. P.; Singh, B. K.; Mohanty, B. P. Natl. Acad. Sci. Lett., 2014, 37(1), 39-44.

18. Mazumder, M. S. A.; Rahman, M. M.; Ahmed, A. T. A.; Begum, M.; Hossain, M. A. Int. J. Sustain. Crop. Prod., 2008, 3(4), 18-23.

19. Mccann, J.C.; Ames, B. N. The American journal of Clinical Nutrition., 2005, 82(2), 281-295.

20. Mizushiqe, T.; Komiya, M.; Onda, M.; Ucihida, K.; Hayamizu, K.; Kabuyama, Y. Biomed. Res., 2017, 38(6), 351-357.

21. Mohanty, B. P.; Hand Book of Fisheries and Aquaculture,ICAR-DKMA, New Delhi., 2010, 2, 843-861.

22. Mohanty, S. N.; Kaushik, S. J. Aquatic Living Res., 1991, 4, 61-64.

23. Molnar, J. A.; Adv. Wound Care., 2014, 3(11), 663-681.

24. Nath, P.; Dam, D.; Kumar, A. India, Rsc. Zoo. Surv. India., 2010, 110(3), 19-33.

25. Rahman, A. K. A. Fresh Water Fishes of Bangladesh, Zoological Society of Bangladesh, University of Dhaka, 2nd Edition, 2005, 116, 115-121.

26. Raji, C. A.; Erickson, K. I.; Lopez, O. L.; Gach, H. M.; Thompson, P. M.; Riverol, M.; Becker, J.
T. Am. J. Prev. Med., 2014, 47(4), 444-451.

27. Sharma, V.; Srivastava, A. Orient. J. Chem., 2016, 32(4), 2171-2178.

28. Sharma, V.; Chaturvedi, N. K.; Saraswat, R. C. Asian J. Chem. and Env. Res., 2010, 3(1), 33-37.

29. Siebeck, O.; Vail, T. L.; Williamson, C. E.; Vetter, R.; Hessen, D.; Zagarese, H.; Little, E.; Balseiro, E.; Modenutti, B.; Seva, J.; Shumate, A. Adv. Limnol., 1994, 43, 101-114,

30. Smith, R. C.; Prezelin, B. B.; Baker, K. S.; Bidigare, R. R.; Boucher, N. P.; Coley, T.; Karentz, T.; Maclntyre, S.; Matlick, H. A.; Menzies, D.; Ondrusek, M.; Wan, Z.; Waters, K. J. Science., 1992, 255, 952-959.

31. Snell, F. D.; Snell, C. T. The Colorimetric Methods of Analysis Including Photometer Method, D.Van Nostrand company Inc. Princton, New Jersey, Toranto, London., 1967, 4, 217, 3, 437-438.

32. Sottp, A. D.; Mazzanti, G.; Savickiene, N.; Starselskyte, R.; Baksenskaite, V.; Giacomo, S. D. Pharmaceutical Biology., 2015, 53(6), 935-938.

33. Walters, C.; Ward, B. Can. J. Fish Aquat. Sci., 1998, 55, 2533-2538.

34. Williamson, C. E.; Metzgar, S. L.; Lovera, P. A.; Ecol Appl., 1997, 7, 1017-1023. 